\title{
Potential of biological arsenite oxidation in sand filtration units at arsenic-iron removal plants (AIRPs) in Bangladesh
}

\author{
Mohammad Mosleh Uddin ${ }^{1} \cdot$ Futoshi Kurisu² $\cdot$ Ikuro Kasuga $^{3} \cdot$ Hiroaki Furumai $^{3} \cdot$ S. M. Atiqul Islam ${ }^{4}$
}

Received: 1 August 2017 / Accepted: 12 March 2019 / Published online: 19 March 2019

(c) The Author(s) 2019

\begin{abstract}
This study is aimed to investigate biological oxidation of arsenic [As(III)] in sand component of arsenic-iron removal plant (AIRP). Water and sand samples were collected from the municipal and household AIRP units (MAIRP and HAIRPs) at Manikganj district, Bangladesh. These samples were analyzed using arsenic speciation cartridge with inductively coupled plasma-mass spectrometry for arsenic and iron detection and phylogenetic analysis based on aoxB gene sequencing. It was observed that arsenic concentration in the raw water, before and after sand filtration, ranged from 13.0-81.0 to 4.0-21.0 $\mu \mathrm{g} / \mathrm{L}$, respectively, which majorly contained reduced arsenic [As(III)] in the inlet and oxidized arsenic $[\mathrm{As}(\mathrm{V})]$ in the outlet. The results of our batch experiments showed that indeed sand unit of MAIRP oxidized As(III) with $36 \mathrm{~g} / \mathrm{h}$ estimated biological oxidation potential which was considered enough to oxidize all the As(III) loading $(6.3 \mathrm{~g} / \mathrm{h})$ in the influent. Additionally, bacterial arsenite oxidase gene (aoxB) was detected in the sand sample and has $80 \%$ sequence similarity with Polymorphum gilvum, an alphaproteobacteria on the phylogenetic tree. This study, therefore, revealed that AIRP sand units have enough potential of biological activity to ensure overall arsenic removal through As(III) oxidation. However, future research is necessary to unfold the basic mechanistic approach explored in this plant for further modification if need arises.
\end{abstract}

Keywords Arsenite $\cdot$ Bangladesh $\cdot$ Biological activity $\cdot$ Sand filtration

\section{Introduction}

Electronic supplementary material The online version of this article (https://doi.org/10.1007/s13201-019-0932-x) contains supplementary material, which is available to authorized users.

Mohammad Mosleh Uddin

uddinmm1987@yahoo.com

1 Department of Biochemistry and Molecular Biology, Mawlana Bhashani Science and Technology University (MBSTU), Santosh, Tangail 1902, Bangladesh

2 Research Center for Water Environment Technology, Graduate School of Engineering, The University of Tokyo, 7-3-1 Hongo, Bunkyu-ku, Tokyo 113-8656, Japan

3 Department of Urban Engineering, Graduate School of Engineering, The University of Tokyo, 7-3-1 Hongo, Bunkyu-ku, Tokyo 113-8656, Japan

4 Department of Civil Engineering, Dhaka University of Engineering and Technology (DUET), Gazipur, Bangladesh
Arsenic water contamination is a common problem among the indigenous of Bangladesh where estimated population of about 35 million are consuming water with arsenic level above $50 \mu \mathrm{g} / \mathrm{L}$ (national standard level) and fivefold higher than the World Health Organization (WHO) guideline (BGS and DPHE 2001; WHO 2011). However, the source of this contamination is controversial but available evidence suggested that agricultural, industrial activities and geological conditions are the major risk factors. Water analysis of the affected area has revealed to contain high level of As(III) species thus rendering the water unsafe for drinking.

The previous studies have shown that ground water contained oxyanions of arsenic species (Cullen and Reimer 1989; Masscheleyn et al. 1991). The predominant form in well-oxidized water is As(V), whereas As(III) occurs mainly in reduced environments. Meanwhile, As(III) has a toxicity that is sixty times greater than that of $\mathrm{As}(\mathrm{V})$ and is difficult to remove without oxidation (Kim et al. 2003).

Many different techniques have been developed to remove arsenic from groundwater. These include adsorption, 
adsorptive filtration, coagulation, membrane filtration, ion exchange and reverse osmosis (Ahmed 2001; Wang and Wai 2004). For most of these technologies, oxidation is required to remove overall arsenic, because As(III) is not adsorbed by solid material such as iron oxides and hydroxides, alumina or clays (Anderson et al. 1976; Lievremont et al. 2003; Gupta et al. 2005). In Bangladesh, simplest common inexpensive technique used is arsenic-iron removal plant (AIRP). The basic principle involves the use of AIRP to remove arsenic using iron as co-precipitating factors. As-Fe complex can be easily removed as sludge by sand filtration.

Oxidation of As(III) under atmospheric condition is an extremely slow process, and hence, chemical oxidants such as chlorine, hydrogen peroxide and ozone are widely used in arsenic removal processes (Kim and Nriagu 2000; Simeonova et al. 2005). Some researchers suggest that microbial activity could also contribute to the oxidation of As(III) (Quéméneur et al. 2008; Hamamura et al. 2009). In fact, many have isolated phylogenetically diverse arsenite-oxidizing bacteria (AsOB) from various environmental samples, including wastewater (Butt and Rehman 2011), sewage (Ito et al. 2012), mines (Santini et al. 2000; Battaglia-Brunet et al. 2006; Lugtu et al. 2009), soil (Bahar et al. 2012) and sediments (Dominguez et al. 2008). Ito et al. (2012) found the contribution of biological As(III) oxidation in a laboratory-scale bioreactor where an isolate closely related to Ensifer adhaerens was immobilized.

Recent molecular studies have revealed the distribution of the diverse arsenite oxidase gene such as aroA/asoA/ aoxB in various As-contaminated environments (Inskeep et al. 2007; Quéméneur et al. 2008; Hamamura et al. 2013,). Contribution of rapid biotic As(III) oxidation was found in spring outflow channel waters, and bacterial arsenite oxidase gene was detected in channel soil samples (Mitsunobu et al. 2013). However, little or no information is available on the role of microbial As(III) oxidation in the sand filtration units of AIRPs.

Thus, this study aimed to examine the contribution of biological activity on As(III) oxidation in the sand filtration units of AIRPs. Arsenic speciation and removal were evaluated in AIRP plants in Bangladesh. A batch experiment with AIRP sand samples was conducted to evaluate oxidative activity. We also identified the bacterial gene for arsenite oxidation in the AIRP sand samples. We therefore concluded that sand units of AIRP offer biological activity that enhances arsenic removal.

\section{Materials and Methods}

\section{Water and sand sample collection}

Water and sand samples were collected from AIRP plants at Manikganj District, Bangladesh. Series of samples were taken from a municipal AIRP (MAIRP) (location: $\left.23^{\circ} 51^{\prime} 05^{\prime \prime} \mathrm{N}, 90^{\circ} 00^{\prime} 04^{\prime \prime} \mathrm{E}\right)$. The plant serves treated water to the municipality. The capacity of the plant was $5500 \mathrm{~m}^{3} /$ day. The schematic of the treatment plant is described in Fig. 1. Briefly, groundwater is pumped up and subjected to primary aeration by exposing the water to the atmosphere (1). Next, the water flows into the sedimentation pond (2) to remove the formed precipitates, followed by gravel filtration (3). After that, the water is again aerated by flowing down a stepped channel (4), where it then flows into the sand filtration unit (5). There were four parallel sand filtration units, the dimensions of which are each $3.35 \mathrm{~m}$ width, $6.4 \mathrm{~m}$ length and $1.5 \mathrm{~m}$ deep. In total, sand volume was $129 \mathrm{~m}^{3}$. The filtrated water is stored in the storage tank (6) before distribution. For this study, water samples were collected from four points, namely Primary aeration, Sedimentation pond, Secondary aeration and Storage tank. Sand samples were collected from the upper part of the sand filtration chamber and from the layer below the precipitated iron.

Also, water and sand samples were taken from three household AIRPs (HAIRPs: H1AIRP, H2AIRP, H3AIRP, respectively) from the same district. HAIRPs are simple treatment plants where the pumped groundwater is poured onto a sand filter unit for arsenic and iron removal. Water was collected before and after the sand filter of the HAIRPs,
Fig. 1 MAIRP treatment plant (1. Primary aeration, 2. Sedimentation pond, 3. Gravel filtration unit 4 . Secondary aeration, 5. Sand filtration unit and 6. Storage tank). Solid line arrows represent the sampling points of the water samples

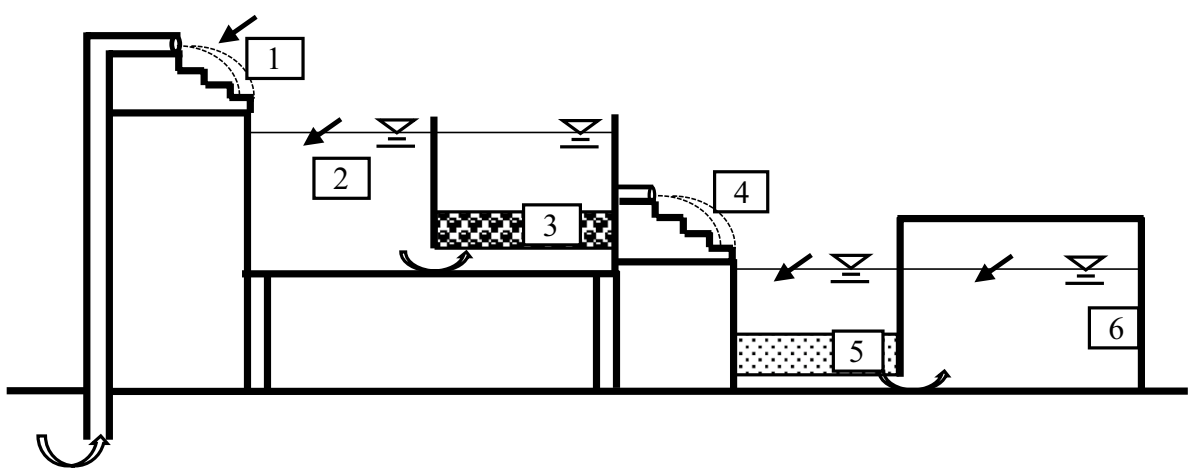

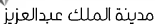

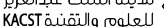


and sand was collected from the sand filter below the iron precipitates observed in all the AIRPs.

In both MAIRP and HAIRPs, approximately, $40 \mathrm{ml}$ of water samples was filtrated through $0.2 \mu \mathrm{m}$ (polyethersulfone, Advantec, Japan) disposable filter and subsequently, half of the water samples were passed through disposable arsenic speciation cartridges (MetalSoft Center, USA) that were attached to a $20-\mathrm{mL}$ disposable syringe (Terumo, Japan) to remove As(V) (details of the cartridge are given in the section of chemical analysis) (http://www.metalsoftc enter.com, accessed 31.11.2012). Thus, we had two portions of water samples each $20 \mathrm{ml}$, one portion is free of $\mathrm{As}(\mathrm{V})$ and the other is not free. Following these separation, the two portions of water samples were then acidified with $\mathrm{HNO}_{3}$ to be kept at $0.1 \mathrm{~N}$. The samples were kept in ice or in the refrigerator during transportation to Japan.

\section{Batch experiment on biological arsenite oxidation}

Three hundred milliliters of synthetic medium amended with $200 \mu \mathrm{g} / \mathrm{L}$ of dissolved As(III) and $2.5 \mathrm{gm}$ of wet sand were incubated at $25{ }^{\circ} \mathrm{C}$ according to Ito et al. (2012) with little modification. The medium consisted of the following ingredients per liter of autoclaved Milli Q water: $\mathrm{MgSO}_{4} \cdot 7 \mathrm{H}_{2} \mathrm{O}$, $4.0 \mathrm{mg} ; \mathrm{NH}_{4} \mathrm{Cl}, 2.0 \mathrm{mg} ; \mathrm{Na}_{2} \mathrm{SO}_{4}, 2.0 \mathrm{mg} ; \mathrm{K}_{2} \mathrm{HPO}_{4}, 0.02 \mathrm{mg}$; $\mathrm{CaCl}_{2} \cdot 2 \mathrm{H}_{2} \mathrm{O}, 0.13 \mathrm{mg} ; \mathrm{FeSO}_{4} \cdot 7 \mathrm{H}_{2} \mathrm{O}, 0.008 \mathrm{mg} ; \mathrm{NaHCO}_{3}$, $1.6 \mathrm{mg}$ and $\mathrm{NaAsO}_{2}, 0.35 \mathrm{mg}[0.2 \mathrm{mg}$ as As(III)]. Abiotic control was also prepared by adding $6.5 \mathrm{~g} / \mathrm{L}$ of sodium azide. We properly stirred the mixture and then took water samples for analysis at interval of $0,6,12,24,36,48$-h from both bottles. The procedure for the analysis was similar as described above. Triplicate batch experiments were done for both test and control batches.

From the balance of $\mathrm{As}(\mathrm{V})$ increase between test batch and abiotic control, capacity of biological arsenic oxidation rate $\left(C_{\text {bao }}, \mu \mathrm{g} / \mathrm{h}\right)$ was calculated:

$C_{\mathrm{bao}}=\frac{S_{\mathrm{f}} \times V}{T \times M}\left(I_{\mathrm{t}}-I_{\mathrm{c}}\right)$

where $S_{\mathrm{f}}$, amount of the sand in the actual sand filtration unit $(\mathrm{g}) ; V$, volume of the media in the batch test (L); $T$, incubation period of the batch test (h); $M$, amount of sand used in batch test $(\mathrm{g}) ; I_{\mathrm{t}}$, increase in dissolved arsenate in the test batch $(\mu \mathrm{g} / \mathrm{L}) ; I_{c}$, increase in dissolved arsenate in the control batch $(\mu \mathrm{g} / \mathrm{L})$

\section{Chemical analysis}

Disposable cartridges made up of $2.5 \mathrm{~g}$ aluminosilicate adsorbent in a polypropylene narrow column of length $10.16 \mathrm{~mm}$ and diameter $0.76 \mathrm{~mm}$ was used to remove As(V) from the samples. At the beginning of this study, the efficiency of this cartridge to remove As(V) was established using sodium meta-arsenite $\left(\mathrm{NaAsO}_{2}\right)$ and sodium arsenate $\left(\mathrm{Na}_{2} \mathrm{HAsO}_{4} \cdot 7 \mathrm{H}_{2} \mathrm{O}\right)$. The cartridge recorded $95 \%$ efficiency in the removal of $\mathrm{As}(\mathrm{V})$ (data not shown). It is therefore adopted in the experiment by measuring the arsenic concentration of the samples before and after passing through cartridges. The balance between the two measurements gave As(V) concentration. For the analysis of arsenic and iron, samples were acidified $(1 \%, \mathrm{v} / \mathrm{v})$ and analyzed by inductively coupled plasma-mass spectrometry (ICP-MS, 7500cx: Agilent Technologies, Japan). Gallium (0.1 mg/L) and scandium $(0.1 \mathrm{mg} / \mathrm{L})$ solutions were used as internal standards for arsenic and iron, respectively, and helium $(\mathrm{He})$ gas mode was used for the analysis of both elements.

\section{PCR amplification, cloning and sequencing of aoxB gene}

Genomic DNA was extracted from $0.5 \mathrm{~g}$ sand using a fast DNA spin kit for soil (MP Biomedicals) following the manufacturer's instructions. The polymerase chain reactions (PCR) for the amplification of arsenite oxidase gene $($ aox $\mathrm{B})$ were carried out in a $50 \mu \mathrm{L}$ reaction mixture containing $100 \mathrm{ng}$ DNA template, $1 \mu \mathrm{L}$ of each forward and reverse primer $(100 \mu \mathrm{M}), 10 \mathrm{X}$ Takara Ex Taq ${ }^{\mathrm{TM}}$ PCR buffer (contains $20 \mathrm{mM} \mathrm{MgCl}$ ) $5 \mu \mathrm{L}$, dNTP mixture $(2.5 \mathrm{mM}$ each dNTP) $4 \mu \mathrm{L}$, TaKaRa Ex Taq HS (5 units/ $\mu \mathrm{L}$ ) $0.25 \mu \mathrm{L}$ and nuclease free water up to $50 \mu \mathrm{L}$. The degenerated primers (69F:5'-TGYATYGTNGGNTGYGGNTAYMA3'; 1374R:5'TANCCYTCYTGRTGNCCNCC-3') (Rhine et al. 2007) were employed for the amplification of arsenite oxidase gene. Nucleic acids extracted from Alcaligenes faecalis strain LMG 3368 were used as a positive control for PCR amplification. All PCR amplifications were performed in the thermal cycler (Veriti 200, Applied Biosystem). The initial denaturation step was begun at $95{ }^{\circ} \mathrm{C}$ for $5 \mathrm{~min}$, followed by 35 cycles of denaturation at $94{ }^{\circ} \mathrm{C}$ for $30 \mathrm{~s}$, annealing at $58{ }^{\circ} \mathrm{C}$ for $30 \mathrm{~s}$, and extending to $72{ }^{\circ} \mathrm{C}$ for $2 \mathrm{~min}$, with a final extension at $72{ }^{\circ} \mathrm{C}$ for $10 \mathrm{~min}$. All PCR products were checked by gel electrophoresis on a $1.5 \%$ agarose gel at $100 \mathrm{~V}$ for $15 \mathrm{~min}$, and the specific bands were visualized under UV trans-illuminator.

PCR products of aox $\mathrm{B}$ gene were purified using a QIAGEN purification plus kit. Cloning was performed using a QIAGEN PCR cloning kit (QIAGEN) according to manufacturer's instruction. PCR products were ligated into a pDrive cloning vector and were transformed into the QIAGEN EZ competent cells. The transformants were then grown on an LB agar plate containing ampicillin, IPTG and X-gel at $37^{\circ} \mathrm{C}$ until colony formation $(\sim 17 \mathrm{~h})$. The positive recombinant colonies (white colonies) were selected according to blue-white screening. The white colonies were directly amplified by using the primers of M13f (-40) and M13r. The 
products were checked by gel electrophoresis and sent to the company (FASMAC, Kanagawa, Japan) for sequencing.

The initial sequence analysis was performed using Blast service (http://blast.ddbj.nig.ac.jp). ClustalW tool was used for sequence alignment. Neighbor-joining phylogenetic tree was constructed by MEGA version 5.0 (Tamura et al. 2011).

\section{Results and discussion}

\section{Removal of arsenic in AIRP}

The concentration of total dissolved arsenic (total D-As) in that raw water (groundwater) of MAIRP as presented in Fig. 2 is $13 \mu \mathrm{g} / \mathrm{L}$ which is considerable lower than the standard value for Bangladeshi drinking water $(50 \mu \mathrm{g} / \mathrm{L})$ (http:// www.dphe.gov.bd, accessed 12.12.2018) but however higher when compared with the WHO guideline value $(10 \mu \mathrm{g} / \mathrm{L})$ (www.who.int/water_sanitation_health/dwq/chemicals/arsen ic.pdf, accessed 12.12.2018). Of the total D-As obtained in the study, very tiny fraction is arsenate $[\mathrm{As}(\mathrm{V})]$ which is consistent with previous reports (DPHE/BGS/MML 1999; Smedley et al. 2001). In groundwater, arsenic mainly exists in two inorganic forms, $\mathrm{As}(\mathrm{III})$ and $\mathrm{As}(\mathrm{V})$; our result thus confirmed the abundance of arsenite [As(III)] though tendency to contain other species of arsenic is not disputable.

Furthermore, the outcome of total D-As after sedimentation increased to $32 \mu \mathrm{g} / \mathrm{L}$. The observation has been linked with changing of the solid phase to the dissolved phase of arsenic. Previous report (Hasan et al. 2009) described mechanism of bioleaching associated with sand filter bed that creates a biofilm in pore space and top of the surface of the bed creating an anaerobic condition that facilitates the bioleaching of arsenic in the outlet water. This mechanism may probably be responsible for the increment in D-As obtained in this study. However, negligible changes in concentration were observed in total D-As after secondary aeration, while D-As(V) remained unchanged (Fig. 2).

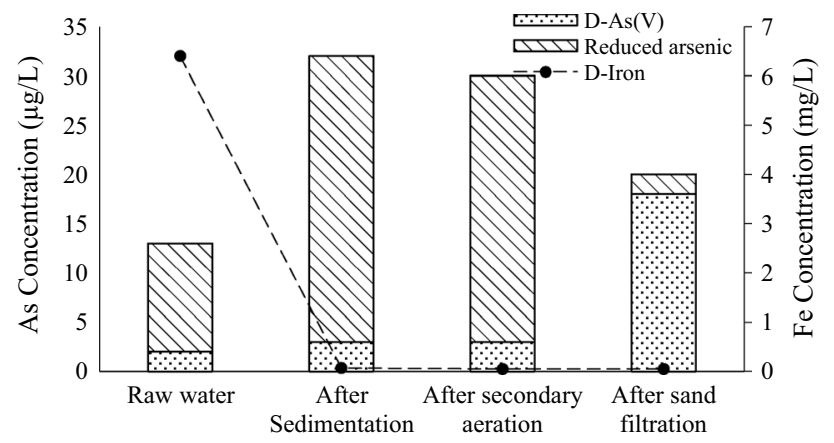

Fig. 2 Concentration of total arsenic and dissolved iron in MAIRP
Importantly, apart from $33.3 \%$ reduction in total D-As obtained after sand filtration, significant reduction and increment in reduced arsenic mainly As(III) and D-As(V) were, respectively, observed. This may suggest that arsenic oxidation took place during sand filtration. Unfortunately, total D-As concentration was not only higher than raw water but also above the WHO value. Thus, MAIRP is not sufficient for arsenic removal. Meanwhile, increment in concentration may be induced by the sediments in the sedimentation pond as described by Hasan et al. (2009). It is therefore suggested that periodic removal of sediment will help to avoid the leaching of arsenic.

Along with arsenic concentration, dissolved $\mathrm{Fe}(\mathrm{D}-\mathrm{Fe})$ concentration was also measured and it was found to reduce from $6.4 \mathrm{mg} / \mathrm{L}$ in the raw water to $0.05 \mathrm{mg} / \mathrm{L}$ both in after secondary aeration and in the storage tank. It has been shown in many studies (Hug et al. 2008, Meng et al. 2002, Roberts et al. 2004) that $\mathrm{As}(\mathrm{V})$ easily co-precipitates with iron and gets removed from the water. Our result (Fig. 2) is consistent with this observation, whereas iron co-precipitation is often depleted in reduced arsenic hence no obvious removal of arsenic in sedimentation pond. Precipitation of $\mathrm{As}(\mathrm{V})$ was limited in due to the lack of enough D-Fe after sand filtration. This phenomenon is in line with Meng et al. (2001).

We also evaluated arsenic and iron concentration before and after sand filtration in the HAIRPs (Fig. 3). Among the three HAIRPs, H1 and H3AIRP removed arsenic well, whereas H2AIRP did not. In H2AIRP, arsenic concentration in the outlet was still higher than the WHO standard $(10 \mu \mathrm{g} / \mathrm{L})$. Most part of the D-As was reduced arsenic in the inlet and then converted to D-As(V) in the plants. Dissolved iron concentration was found to differ in the inlet water of H1AIRP(15 mg/L), H3AIRP(13 mg/L) and $0.8 \mathrm{mg} / \mathrm{L}$ in H2AIRP, but all the plants have similar iron concentration $(0.06 \mathrm{mg} / \mathrm{L})$ after sand filtration. The low dissolved iron concentration in H2AIRP seems not enough to co-precipitate with arsenic and thereby arsenic removal is inadequate.

\section{Biological activity of As(III) oxidation}

Investigation of biological activities responsible for arsenic oxidation is the main focus here. This was done by batch experiment to observe the impact of microbial activity on As(III) oxidation using sodium arsenite solution on sand sample. An abiotic control was prepared by adding sodium azide. Here, the balance between total D-As and D-As(III) should be D-As(V).

The total D-As and D-As $(\mathrm{V})$ concentration in the batch experiment with MAIRP (Fig. 4) and HAIRPs sands (Figs. S1-S3). In both cases, the total D-As in test and control batches are comparable and gradually decreasing along the incubation time. This may be due to the abiotic activities such as adsorption of arsenic onto the sand particulates or 

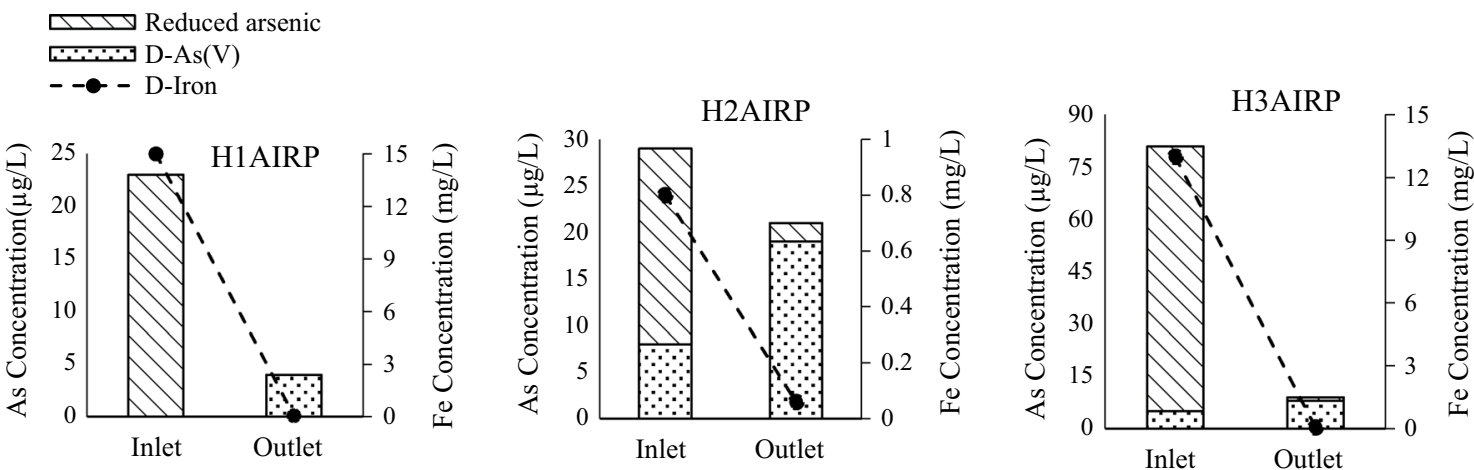

Fig. 3 Concentration of dissolved arsenic and iron in the HAIRPs

Fig. 4 Arsenic concentration in test (a) and control (b) batch
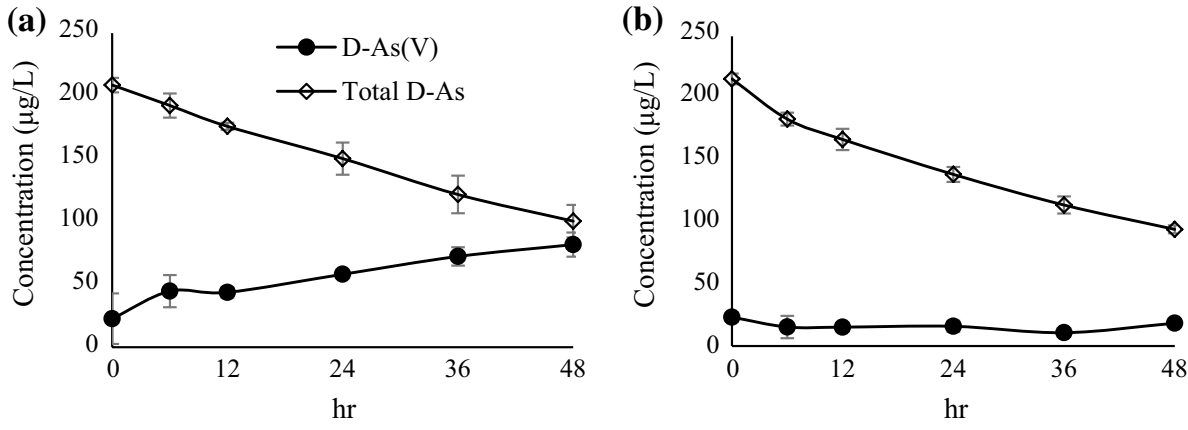

the precipitation of arsenic from the dissolved phase to the solid phase.

A gradual increase in D-As(V) was observed in the test case, whereas in the abiotic control it remained constant throughout the incubation period. At the beginning of the batch test, D-As(V) originated from the stock solution of sodium arsenite, as we observed even in the fresh solution. After 48-h incubation, it was found that the amount of D-As(III) was $19 \mu \mathrm{g} / \mathrm{L}$ in the test case and $76 \mu \mathrm{g} / \mathrm{L}$ in the control. Thus, it depicts more removal of D-As(III) in the test batch which can ascribed to the oxidation of D-As(III) to D-As(V). Hence, the oxidation is biological as it occurred only in the test batch.

Despite variation in the concentration of D-As(V) as observed in this study, total D-As concentration remained unchanged in both test and control batches. Thus, suggesting that precipitation and/or adsorption of D-As was not enhanced by the oxidation of As(III) to As(V). We noted that, before this experiment, the sand was washed to remove Fe particles to reduce the D-As removal rate, as it was too rapid to observe biological arsenite oxidation with the original sand in the preliminary test.

We next considered the potential of biological oxidation in the AIRP unit. Based on the batch experiment of MAIRP, the arsenite oxidation rate was $0.15 \mu \mathrm{g} / \mathrm{h} / \mathrm{g}$-sand. This further gave assumptive estimation of $36 \mathrm{~g} / \mathrm{h}$ for biological oxidation rate. The loading of the reduced arsenic to the sand filtration unit is $6.3 \mathrm{~g} / \mathrm{h}$ (calculated from $27 \mu \mathrm{g} / \mathrm{L}$ arsenite in the influent to the sand filtration unit and the flow rate of $5500 \mathrm{~m}^{3} /$ day). Therefore, it can be inferred that sand has enough capacity to biologically oxidize all arsenite in the influent as shown in (Table S1).

\section{Detection of arsenite oxidase aoxB gene sequences}

With degenerated oligonucleotide primers, a fragment of the large subunit of aoxB was amplified from the genomic DNA extracted from the sand samples. The aox $\mathrm{B}$ gene was detected from the MAIRP sand sample. The size of the amplicon was approximately $1400 \mathrm{bp}$, as expected. The PCR product was cloned, and four clones were obtained for sequencing.

Figure 5 shows the phylogenetic relationship of the cloned sequences. The clones had $80 \%$ similarity to the arsenite oxidase gene of Polymorphum gilvum, an Alphaproteobacteria. This bacterium was previously isolated from a crude oil-polluted saline soil which was used as source of its carbon (Price et al. 2013). Polymorphum gilvum was not known to conduct arsenic metabolism even though it had the arsenite oxidase gene.

In this experiment, all the data put together demonstrated the biological oxidation of arsenite occurred and the aox $\mathrm{B}$ 
Fig. 5 Neighbor-joining tree showing phylogenetic positions of aoxB gene sequences (CL1, CL2, CL7 and CL10 are the cloned sequences)

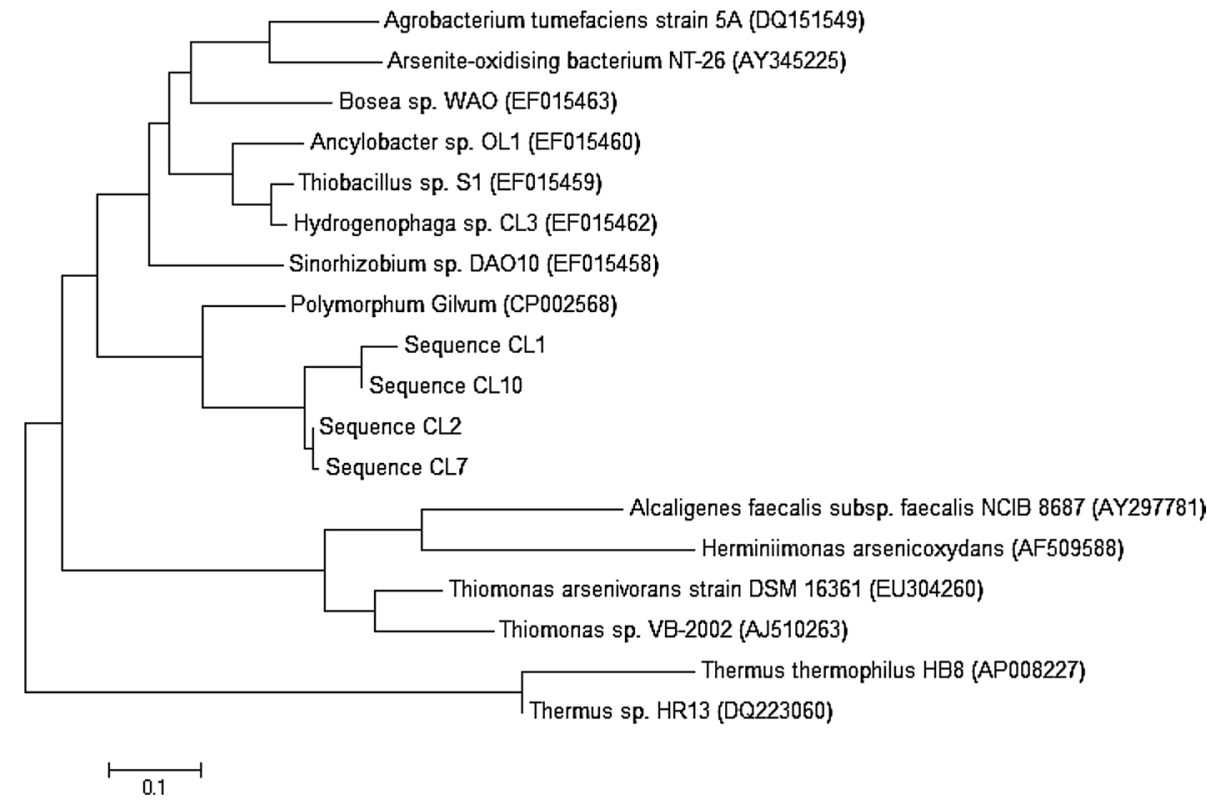

gene retrieved play role in the oxidation. Further study is thereby necessary to clarify the arsenite-oxidizing activity of the bacteria identified in the study.

\section{Conclusion}

This study underscores the inevitability of biological oxidation in the removal of arsenic in all AIRPs and arsenite oxidation potential was high enough to oxidize all arsenite in the water. Our analysis presumed that biological oxidation observed was as a result of aoxB gene which was $80 \%$ linked to Polymorphum gilvum. However, contrary to our assumption, the performance of MAIRP in the removal of arsenic is not satisfactory. Therefore, periodic removal of sediment is recommended to mitigate this inefficiency in the municipal water distribution in Manikganj District, Bangladesh.

Acknowledgment This study was financially supported by the Kurita Water and Environment Foundation, Japan. The author would like to thank Dr. Keisuke Kuroda for his assistance in ICPMS analysis and Dr. Mana Noguchi for her assistance in molecular biology work.

Open Access This article is distributed under the terms of the Creative Commons Attribution 4.0 International License (http://creativeco mmons.org/licenses/by/4.0/), which permits unrestricted use, distribution, and reproduction in any medium, provided you give appropriate credit to the original author(s) and the source, provide a link to the Creative Commons license, and indicate if changes were made.

\section{References}

Ahmed MF (2001) An overview of arsenic removal technologies in Bangladesh and India. In: Technologies for arsenic removal from drinking water. Bangladesh University of Engineering and Technology, Dhaka; United Nations University, pp 251-269

Anderson MA, Ferguson JF, Gavies J (1976) Arsenate adsorption on amorphous alumina hydroxide. J Colloid Interface Sci 54:391-399

Bahar MM, Megharaj M, Naidu R (2012) Arsenic bioremediation potential of a new arsenite-oxidizing bacterium Stenotrophomonas sp. MM-7 isolated from soil. Biodegradation 23:803-812

Battaglia-Brunet F, Joulian C, Garrido F, Dictor MC, Morin D, Coupland K, Johnson DB, Hallberg KB, Baranger P (2006) Oxidation of arsenite by Thiomonas strains and characterization of Thiomonas arsenivorans sp. nov. Antonie Van Leeuwenhoek Int J 89:99-108

BGS and DPHE (2001) Arsenic contamination of groundwater in Bangladesh. BGS technical report, WC/00/19

Butt SA, Rehman A (2011) Isolation of arsenite-oxidizing bacteria from industrial effluents and their potential use in wastewater treatment. World J Microbiol Biotechnol 27:2435-2441

Cullen WR, Reimer KJ (1989) Arsenic speciation in the environment. Chem Rev 89:713-764

Dominguez EG, Mumford A, Rhine ED, Paschal A, Young LY (2008) Novel autotrophic arsenite-oxidizing bacteria isolated from soil and sediments. FEMS Microbiol Ecol 66:401-410

DPHE/BGS/MML (1999) Groundwater studies for arsenic contamination in Bangladesh, phase: rapid investigation phase, vol 6 . BGS/MML technical report to department of International Development, UK

Gupta VK, Saini VK, Jain N (2005) Adsorption of As(III) from aqueous solutions by iron oxide-coated sand. J Colloid Interface Sci 288:55-60

Hamamura N, Macur RE, Korf S, Ackerman G, Taylar WP, Kozubal M, Reysenbach AL, Inskeep WP (2009) Linking microbial oxidation of arsenic with detection and phylogenetic analysis of arsenite oxidase genes in diverse geothermal environments. Environ Microbiol 11:421-431 
Hamamura N, Fukusima K, Itai T (2013) Identification of antimonyand arsenic-oxidizing bacteria associated with antimony mine tailing. Microbes Environ 28(2):257-263

Hasan MK, Fukushi K, Nakajima F, Yamamoto K (2009) Bioleaching of arsenic in a drinking water treatment process. J Water Supply Res Technol Aqua 58(6):395-404

Hug SJ, Leupin OX, Berg M (2008) Bangladesh and Vietnam: different groundwater compositions require different approaches to arsenic mitigation. Environ Sci Technol 42:6318-6323

Inskeep WP, Macur RE, Hamamura N, Warelow TP, Ward SA, Santini JM (2007) Detection, diversity and expression of aerobic bacterial arsenite oxidase genes. Environ Microbiol 9(4):934-943

Ito A, Miura JI, Ishikawa N, Umita T (2012) Biological oxidation of arsenite in synthetic groundwater using immobilized bacteria. Water Res 46(15):4825-4831

Kim MJ, Nriagu J (2000) Oxidation of arsenite in groundwater using ozone and oxygen. Sci Total Environ 247(1):71-79

Kim JY, Davis AP, Kim KW (2003) Stabilization of available arsenic in highly contaminant mine tailings using iron. Environ Sci Technol 37(1):189-195

Lievremont D, N'negue M-A, Behra P, Lett M-C (2003) Biological oxidation of arsenite: batch reactor experiments in presence of kutnahorite and chabazite. Chemosphere 51(5):419-428

Lugtu RT, Choi SC, YS O (2009) Arsenite oxidation by a facultative chemolithotrophic bacterium SDB1 isolated from mine tailing. $\mathrm{J}$ Microbiol 47(6):486-492

Masscheleyn PH, Delaune RD, Patrick WH Jr (1991) Effect of redox potential and $\mathrm{pH}$ on arsenic speciation and solubility in a contaminated soil. Environ Sci Technol 25(8):1414-1419

Meng ZG, Korfiatis GP, Christodoulatos C, Bang S (2001) Treatment of arsenic in Bangladesh well water using a household co-precipitation and filtration system. Water Res 35:2805-2810

Meng XG, Korfiatis GP, Bang SB, Bang KW (2002) Combined effects of anions on arsenic removal by iron hydroxides. Toxicol Lett 133(1):103-111

Mitsunobu S, Hamamura N, Kataoka T, Shiraishi F (2013) Arsenic attenuation in geothermal stream water coupled with biogenic arsenic(III) oxidation. Appl Geochem 35:154-160

Price ER, Lesniewski R, Nitzsche SK, Meyerdierks A, Saltikov C, Pichler T, Amend J (2013) Archaeal and bacterial diversity in an arsenic-rich shallow-sea hydrothermal system undergoing phase separation. Front Microbiol 4:158. https://doi.org/10.3389/fmicb .2013 .00158

Quéméneur M, Heinrich-salmeron A, Muller D, Jauzein M, Philippe N, Garrido F, Joulian C (2008) Diversity surveys and evolutionary relationships of aox $\mathrm{B}$ genes in aerobic arsenite-oxidizing bacteria. Appl Environ Microbiol 74(14):4567-4573

Rhine ED, Ni Chadhain SM, Zylstra GJ, Young LY (2007) The arsenite oxidase genes (aroAB) in novel chemoautotrophic arsenite oxidizers. Biochem Biophys Res Commun 354(3):662-667

Roberts LC, Hug SJ, Ruettimann T, Billah MM, Khan AW, Rahman MT (2004) Arsenic removal with iron(II) and iron(III) in waters with high silicate and phosphate concentrations. Environ Sci Technol 38:307-315

Santini JM, Sly LI, Schnagl RD, Macy JM (2000) A new chemolithoautotrophic arsenite-oxidizing bacterium isolated from a gold mine: phylogenetic, physiological, and preliminary biochemical studies. Appl Environ Microbiol 66:92-97

Simeonova DD, Micheva K, Muller DAE (2005) Arsenite oxidation in batch reactors with alginate-immobilized ULPAs 1 strain. Biotechnol Bioeng 91:441-446

Smedley P, Kinniburgh D, Huq I, Luo Z, Nicolli HB (2001) International perspective on naturally-occurring arsenic problems in groundwater. In: Chappell WR, Abernathy CO, Calderon RL (eds) Arsenic exposure and health effects IV. Elsevier, Amsterdam, pp 9-25

Tamura K, Peterson D, Peterson N, Stecher G, Nei M, Kumar S (2011) MEGA5: molecular evolutionary genetics analysis using maximum likelihood, evolutionary distance, and maximum parsimony methods. Mol Biol Evol 28:2731-2739

Wang SJ, Wai MC (2004) Arsenic in drinking water-a global environmental problem. J Chem Educ 81(2):207

WHO (2011) Guideline for drinking-water quality, fourth edition. Available on the webstite https://www.who.int/water_sanitation _health/publications/2011/dwq_guidelines/en/

Publisher's Note Springer Nature remains neutral with regard to jurisdictional claims in published maps and institutional affiliations. 